\title{
POVERTY AND HEALTH DISPARITIES
}

\section{Breaking the Intergenerational Cycle of Disadvantage: The Three Generation Approach}

Tina L. Cheng, MD, MPH, a,b Sara B. Johnson, PhD, MPH, ,a,b Elizabeth Goodman, MD ${ }^{c, d}$

\begin{abstract}
Health disparities in the United States related to socioeconomic status are persistent and pervasive. This review highlights how social disadvantage, particularly low socioeconomic status and the health burden it brings, is passed from 1 generation to the next. First, we review current frameworks for understanding the intergenerational transmission of health disparities and provide 4 illustrative examples relevant to child health, development, and well-being. Second, the leading strategy to break the cycle of poverty in young families in the United States, the 2-generation approach, is reviewed. Finally, we propose a new 3-generation approach that must combine with the 2-generation approach to interrupt the intergenerational cycle of disadvantage and eliminate health disparities.
\end{abstract}

Eliminating health disparities is a national priority codified in both Healthy People $2020^{1}$ and in calls for action from multiple scientific and public health organizations. ${ }^{2,3}$ Today American children are more likely than adults to be living in poverty. ${ }^{4}$ A vast literature has documented the existence of social inequalities in health and the persistent effects of childhood social adversities throughout the life course. ${ }^{5-11}$ Furthermore, social disadvantage clusters in families across multiple generations. ${ }^{12}$ Children in poverty are more likely to become lower socioeconomic status (SES) adults who accumulate less wealth to pass on to future generations. ${ }^{5}$ To break the intergenerational cycle of disadvantage, the frameworks that inform clinical care, policy, and research must expand beyond parentchild dyadic family health to include an intentional and proactive focus on improving the health, well-being, and social circumstances of future generations.
This review highlights how social disadvantage, particularly low SES and the health burden it brings, is passed across generations and provides evidence to justify a forwardlooking paradigm shift. First, we review current frameworks for understanding the intergenerational transmission of health disparities. Next, to link research to programs and policy we highlight the current leading strategy to address child poverty: the 2-generation approach. ${ }^{13,14}$ We then provide 4 illustrative examples of relevant health risks and related 2-generation interventions. Finally, we suggest that 2-generation approaches, although extremely important, are alone insufficient and propose a 3-generation approach. Acknowledging growing research on biological, behavioral, social, and environmental influences across generations, the 3-generation approach appreciates the importance of life course trajectories and extends the programmatic and policy focus beyond early childhood through

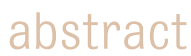

a Department of Pediatrics, Johns Hopkins School of Medicine, Baltimore, Maryland; 'bepartment of Population, Family and Reproductive Health, Bloomberg School of Public Health, Baltimore, Maryland; ${ }^{C}$ MassGeneral Hospital for Children, Boston, Massachusetts; and ${ }^{d}$ Department of Pediatrics, Harvard Medical School, Boston, Massachusetts

Drs Cheng, Johnson, and Goodman conceptualized and drafted the manuscript and reviewed and revised the manuscript, and all authors approved the final manuscript as submitted.

DOI: $10.1542 /$ peds.2015-2467

Accepted for publication Dec 30, 2015

Address correspondence to Tina L. Cheng, MD, MPH, Johns Hopkins University General Pediatrics \& Adolescent Medicine, 200 N. Wolfe St, Suite 2055, Baltimore, MD 21287. E-mail: tcheng2@jhmi.edu

PEDIATRICS (ISSN Numbers: Print, 0031-4005; Online, 1098-4275)

Copyright $(\bigodot 2016$ by the American Academy of Pediatrics

To cite: Cheng TL, Johnson SB, Goodman E. Breaking the Intergenerational Cycle of Disadvantage: The Three Generation Approach Pediatrics. 2016;137(6):e20152467 
adolescence and young adulthood, when individuals may become parents. This approach looks forward in time toward health promotion of both current and future generations. The frameworks and approaches are summarized in Table 1.

\section{THEORETICAL FRAMEWORKS FOR THE INTERGENERATIONAL TRANSMISSION OF HEALTH DISPARITIES}

In the latter half of the 20th century, nature versus nurture was the dominant paradigm for understanding intergenerational transmission of health risks. Intergenerational mechanisms were conceptualized as a function of genetic inheritance (nature) or a bad socioemotional environment (nurture). Recognizing the key role environments play in modulating gene expression, today the transmission of health and well-being across generations is understood as a function of gene-environment interactions that occur in a specific shared context. ${ }^{21}$

Although it is understood that the environments of families who experience multigenerational disadvantage are often characterized by high levels of psychosocial and physical stressors and lack of buffering resources, how these environments get under the skin to create health disparities remains puzzling. Over the past 2 decades, multiple frameworks have been used to understand these mechanisms. Seminal work comes from both social epidemiology and neuroscience. In relation to child health and well-being, the developmental origins of adult disease (DoHAD) framework and the field of fetal programming, ${ }^{22}$ now called biological "conditioning,"11,23 are perhaps the best known.

DoHAD is closely linked with the work of Barker and colleagues, who noted that children who were in utero during the World War II Dutch Winter Famine, when starvation

TABLE 1 Theoretical Frameworks and Intervention Approaches to Address the Intergenerational Cycle of Disadvantage

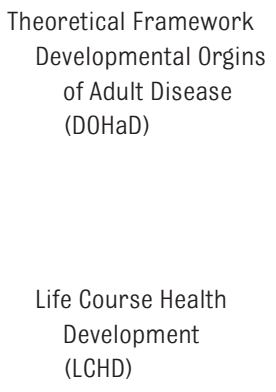
of Adult Disease (DOHaD)

\section{Life Course Health Development (LCHD)}

Allostatic Load

Intervention Approach 2-generation

3-generation

was widespread and profound, were small for gestational age (SGA) and that adults who had been SGA infants were at higher risk for type 2 diabetes and metabolic syndrome, diseases associated with large for gestational age infants and increased adiposity and that the hypothalamic pituitary adrenal axis was the mechanistic link. ${ }^{24-27}$ The Barker Hypothesis suggests that these individuals were programmed in utero to hold on to nutrients, an adaptive step if the environment is nutrient-poor, as it was during the famine, creating a "thrifty phenotype" that increased risk for disease as associated with increased adiposity, even after adjustment for adult body size. ${ }^{15,26,28-30} \mathrm{~A}$ Helsinki birth cohort also demonstrated the association between fetal growth retardation and increased risk for obesity, type 2 diabetes, and heart disease in adults. ${ }^{31-33}$ Despite challenges to its validity, ${ }^{34}$ a wealth of studies, including epigenetic studies, have supported the DoHAD framework which focuses on fetal and intrauterine exposures. ${ }^{25}$

In parallel to these studies, intergenerational transmission of biological traits through social 
factors was also being investigated. In elegant work with rats, Meaney and colleagues showed epigenetic changes in offspring due to variations in maternal care. ${ }^{35,36}$ Dams with high licking and grooming behaviors produced well-adjusted pups across generations, whereas low licking and grooming dams produced skittish rats. Pups from low licking and grooming dams cross-fostered with high licking and grooming dams were also well-adjusted. In adulthood, these cross-fostered pups produced offspring similar to the cross-fostered, rather than their birth phenotype. These behavioral changes were related to epigenetically induced changes, including glucocorticoid receptor expression in the hippocampus and neurotransmitter receptor expression in the amygdala. ${ }^{36,37}$ These epigenetic studies provide excellent examples of the evolving nature of the $\mathrm{DOHaD}$ framework beyond epidemiology to a diversity of scientific fields.

The DoHAD framework focuses primarily on the role of exposures from conception to infancy. Although these are critical developmental periods, growth and plasticity occur throughout the life course. The Life Course Health Development (LCHD) framework, widely disseminated particularly in relation to health policy, acknowledges the continued plasticity of individuals across the life course, characterizing health and well-being as an emergent property of individuals, shaped by their interactions with their environment over time. ${ }^{16,38}$ Popularization of the LCHD framework reflects the broader evolution of theories of biological development beyond the dichotomy between nature and nurture to the dynamic interplay between nature and nurture in determining individuals' life course trajectories. ${ }^{39}$

LCHD is a powerful, forward-focused theoretical framework. Although person-context interactions over time are at its core, the LCHD framework does not propose mechanisms to understand how such interactions create health disparities. McEwen's allostatic load theory fills this gap. ${ }^{19}$ Allostasis ${ }^{18}$ describes the process through which an organism adapts to an environmental stressor. Adaptation, which involves neuroendocrine and autonomic nervous system responses, occurs at each instance a stressor is encountered. Over time, repeated cycles of allostasis lead to cumulative wear and tear on these regulatory systems: high allostatic load causing dysregulation and ultimately disease. Low SES can lead to increased allostatic load and, over time, health disparities. ${ }^{20}$ Recent studies support links between poverty and changes in the biological mediators of allostasis. ${ }^{40-42}$

\section{BREAKING THE CYCLE OF DISADVANTAGE: THE 2-GENERATION APPROACH}

The 2-generation approach is today's leading strategy to break the cycle of poverty in young families. ${ }^{13,14,43}$ This whole-family approach acknowledges the primacy of the family in shaping health and developmental outcomes for children. ${ }^{13,43}$ The 2-generation approach (Fig 1 ${ }^{43,44}$ ) aims to improve families' circumstances by supporting parents in their roles as parents and as workers, thereby helping both generations to escape poverty. Fewer programs have explicitly focused on parents' health to improve child health and well-being outside of programs for pregnant women. ${ }^{45}$ High-risk families are the target for many 2-generation programs that attempt to ameliorate the effects of poverty on health and well-being.

\section{ILLUSTRATIVE EXAMPLES}

We describe 4 examples that illustrate the complex mechanisms underlying how social disadvantage not only creates health risk, but also

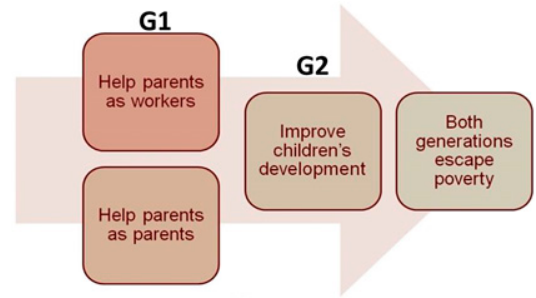

FIGURE 1

Two-generation approach. G1, generation 1 parents; G2, generation 2, child. (Adapted with permission from Schmit S, Matthews H, Golden 0 . Thriving children, successful parents: a twogeneration approach to policy. CLASP Policy Solutions; July 9, 2014. Available at: http:// www.clasp.org/resources-and-publications/ publication-1/Two-Gen-Brief-FINAL.pdf. Accessed June 14, 2015.)

persists across generations. These include a sociostructural factor (child poverty), a biological contextual factor (low birth weight; LBW), a social contextual factor (parenting), and a health-related factor (mental health). Each example contains Generation 1 (G1), Generation 2 (G2), and Generation 3 (G3) pathways, highlighting the reciprocal and dynamic nature of the relationship between SES and health in the context of intergenerational family well-being (Fig 2). ${ }^{46}$ Because this review is child-centric, we refer to a child's generation as G2, his or her parents as G1, and his or her potential offspring as G3.

\section{Child Poverty}

Children are the most likely sector of the US population to live in poverty. ${ }^{4}$ Poverty in early childhood is directly related to a child's adult earnings, occupational productivity, use of public benefits, and risk of health conditions, such as cardio-metabolic disease and arthritis, which limit adult work.5,47 Multigenerational legacies of racism, segregation, and systematic economic disenfranchisement particularly disadvantage poor families of color and limit economic mobility and opportunity. ${ }^{48}$ Children raised in poverty often fail to accumulate the "health capital" that facilitates 


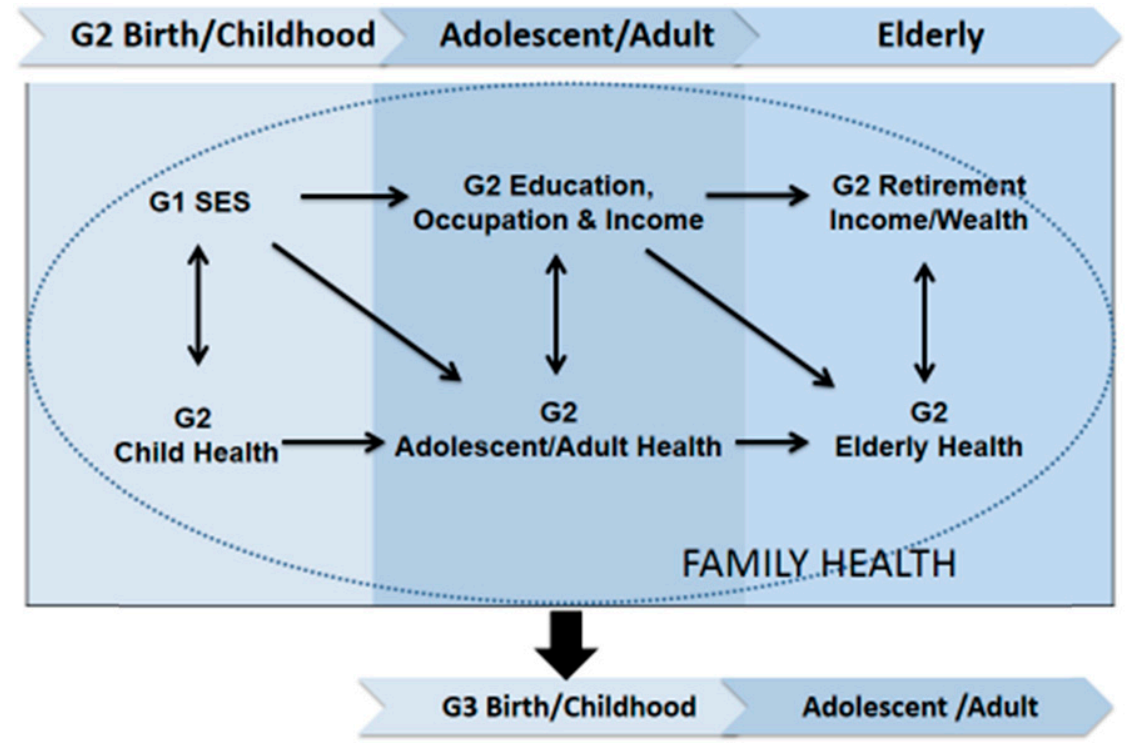

FIGURE 2

Dynamic relationship of SES and health across generations. G1: generation 1, parents; G2: generation 2, child; G3 generation 3, future offspring.

later educational attainment, peer relationships, and ability to parent, all of which contribute substantially to LCHD and transmission of health risk across generations. ${ }^{21,49,50}$ Today's widening education gap suggests that the contribution of adolescent capacities (or lack thereof) to population-level patterns of generational disadvantage is arguably greater now than in the past. ${ }^{49}$ Thus, a child (G2) born to poor parents (G1) is likely to remain poor as an adult (G2) and, if he or she becomes a parent, to raise poor children (G3). Head Start, which began in 1965 as part of the War on Poverty, is one of the best known examples of a 2-generation approach. Head Start now provides yearround, full-day services for a million preschool-aged children and their families across the United States. ${ }^{51}$

\section{LBW}

Racial and SES disparities in LBW are a major public health problem..$^{50,52}$ SGA infants like those studied by Barker are 1 class of LBW infants. SES affects factors such as prenatal nutrition, ${ }^{53}$ and maternal (G1) health behaviors such that infants born to disadvantaged mothers are at increased health risk for LBW. ${ }^{12,54}$ LBW infants (G2) face poorer health and well-being across their life spans; they are at higher risk of adult cardiometabolic disease, emotional and behavioral problems, and cognitive problems. ${ }^{55}$ Mechanisms underlying these disparities include shared genetics and epigenetic changes, as well as continuity in social conditions across generations. ${ }^{50,56,57}$ For example, mothers (G1) who were born LBW are $\sim 50 \%$ more likely to give birth to LBW infants (G2), compared with mothers born heavier, even among sisters. ${ }^{50}$ Being born LBW (G2) is related to lower educational attainment and poorer adult health, both of which affect parenting. ${ }^{50,55}$ Thus, disadvantage leads to health and behavioral risks across a woman's lifetime (G1) which increases her risk of having a LBW infant (G2); if that infant is a girl, the child is at increased risk of having an LBW infant (G3). Historically, 2-generation approaches to addressing LBW have centered around efforts to expand access to and utilization of prenatal and intrapartum care, particularly for low-income and minority women.

\section{Parenting}

Parenting is a key conduit through which disadvantage and poor health are passed across generations. ${ }^{58-62}$ Positive parenting (ie, warm and supportive parent-child relationships) is more likely to facilitate the transmission of higher SES through greater educational attainment, better adjustment, and fewer antisocial behaviors, whereas negative parenting is more likely to have the opposite effects. ${ }^{61,63-65}$ Parenting behaviors are transmitted across generations through a variety of mechanisms, such as attachment ${ }^{58-61}$ and epigenetic regulation of the genome ${ }^{62}$ In turn, children's (G2) social competence and personality predict parental (G1) investments, family stress, and, ultimately, their own (G2) SES as adults. ${ }^{63,66}$ Individuals exposed to harsh discipline, aggressive parenting, and poor supervision during childhood and adolescence (G2) display similar parenting behaviors when they become parents, reinforcing the relationships among parenting, social competence, and achievement across generations (G3). ${ }^{61,65}$ Finally, a number of intergenerational studies provide compelling evidence of continuity in parenting behaviors and health risk. $^{65-74}$ In a 12 -year family study, grandparents' poverty during adolescence predicted earlier childbearing and more harshness in parents and more behavioral problems in their 2- to 3-year-old children. ${ }^{66}$ These behavior problems, in turn, elicited more harshness from their parents at 3 to 4 years of age. These findings support others suggesting that children's social competence and personality predict parental investments, family stress, and, ultimately, their adult SES. ${ }^{63,66}$

Among the most widely implemented 2-generation approaches for 
improving parenting in at-risk families is the Federal Home Visiting Program, which provided more than 1.4 million home visits between 2012 and early 2015. Home visiting is designed to promote maternal and child health and safety, increase parenting knowledge and responsiveness, and promote the parent-child bond. ${ }^{75}$

\section{Mental Health}

There is mounting evidence that poor mental health is a key mechanism in the intergenerational transmission of disadvantage. As a group, individuals who suffer from mental illness have lower SES than those who do not. ${ }^{76}$ Both social selection (ie, those who have mental illness are more likely to be poor because of downward mobility) and social causation (ie, the stress of being poor increases the risk of mental illness) likely play a role, although the weight of the evidence suggests social causation has greater impact. ${ }^{76-78}$ A 3-generation retrospective study found that the likelihood a parent with major depression would have a child with a psychiatric disorder (principally anxiety disorder) varied by grandparents' major depression status. ${ }^{79,80}$ Both genetic and environmental factors likely account for these relationships. Similarly, recent research supports the role of exposure to family violence in the intergenerational transmission of antisocial behavior, including some mental disorders (ie, posttraumatic stress disorder and alcoholism) and emotional impulsivity and aggression. ${ }^{81}$
A 2-generation approach to addressing mental health as a source of disadvantage includes identifying both parent and child mental health problems in pediatric primary care and referrals to appropriate services. $^{82}$

\section{Summary}

Two-generation approaches with high-risk families are critical.

However, although necessary, they are not sufficient to interrupt cycles of intergenerational disadvantage. Evidence suggests that social disadvantage decreases children's ability to gain the cognitive, emotional, and behavioral capacities needed for optimal academic and social achievement in adolescence and to become gainfully employed, engaged citizens, and caring partners and friends when they transition to adulthood. This disadvantage extends throughout an individual's lifetime, within families, and across generations. Consequently, we argue that, alongside the 2-generation approach, a new, forward thinking 3-generation approach rooted in primary prevention is also needed.

\section{THE 3-GENERATION APPROACH}

Current approaches acknowledge the role of disadvantage in shaping health and well-being, not just in families, but across generations. To interrupt cycles of poorer health and disadvantage, the implications of an individual's interaction with his or her environment over the life course must be paired with an understanding of the implications for his or her family and for subsequent generations. Specifically, our approaches must be proactive in anticipating and ameliorating the impact of family circumstances, experiences, and behaviors on the health, well-being, and capacities of future generations.

Building on previous frameworks, the 3-generation approach recognizes the intergenerational transmission of health, well-being, wealth, and social status. It emphasizes the need to universally support children's development, health, and functioning to facilitate both a productive adulthood and their potential to parent the next generation. There is ample scientific evidence supporting the formative role of early childhood. ${ }^{7,83}$ It is difficult to make up for adverse childhood experiences or inadequacies in parental nurturance, stimulation, and other determinants of early childhood development after the fact.7,83 Investing in human capital, specifically parents, is critical to protecting children's potential at the population level. ${ }^{83,84}$ However, opportunities to optimize parenting capacities begin long before individuals have made choices about family formation. Thus, a longer-term investment is needed not just for high-risk families (2-generation approach) but for all children, adolescents, and families (3-generation approach). The 3-generation approach (Fig 3) focuses on the following: (1) helping parents (G1) as workers and as parents as in the 2-generation approach; (2) improving child and adolescent (G2) health and wellbeing, development, education, and social circumstances for successful and productive adulthood; and (3) optimizing adolescents' and young adults' capacity for planning and parenting future offspring (G3). Figure 4 expands on Ascend: the Aspen Institute's ${ }^{43}$ depiction of the 2-generation model, shifting the focus from the child-parent family unit to include potential future generations.

Whereas the life course approach has been criticized for minimizing the impact of events and interventions that occur beyond early life, ${ }^{85}$ the 3-generation approach highlights the importance of both early childhood and adolescence/early adulthood and the interactions among generations. Patterns of behavior established in adolescence persist into adulthood, and many of the capacities that facilitate a healthy transition to adulthood (emotional and cognitive regulation, persistence, positive peer-partner relationships) also support the ability to parent the next generation. The current care 
delivery system is oriented toward preventing and managing adolescent risk behaviors. The 3-generation approach emphasizes risk reduction but highlights the need for policies supporting future planning, including the preconception health and education of young women and men, reproductive life planning, and socioemotional skills development.

\section{IMPLICATIONS OF A 3-GENERATION APPROACH}

The 3-generation approach has implications for clinical care, policy, and research. In the clinical realm, it emphasizes childhood, adolescence, and young adulthood as critical periods during which the health care system and social programs must play a larger role in optimizing (1) youth's capacities for educational attainment, transition to work, and adult productivity; (2) preconception health; (3) reproductive life planning; and (4) parenting skills and capacities.

\section{Building Youth's Capacities}

Health and educational outcomes interact to drive health and educational disparities (Fig 2). Poor physical and mental health in childhood and adolescence negatively affect attention, learning, persistence, and school engagement, as well as future educational achievement and attainment. Promoting a healthy foundation for all children is key to closing the achievement gap and reducing health disparities. To date, however, health and educational interventions have been implemented separately, limiting their overall impact in both sectors. Making children's health and educational progress a shared responsibility of primary care and our educational system, as well as implementing new models to integrate health and education sectors will help both today's and future children escape poverty. The 3-generation approach argues for
G1

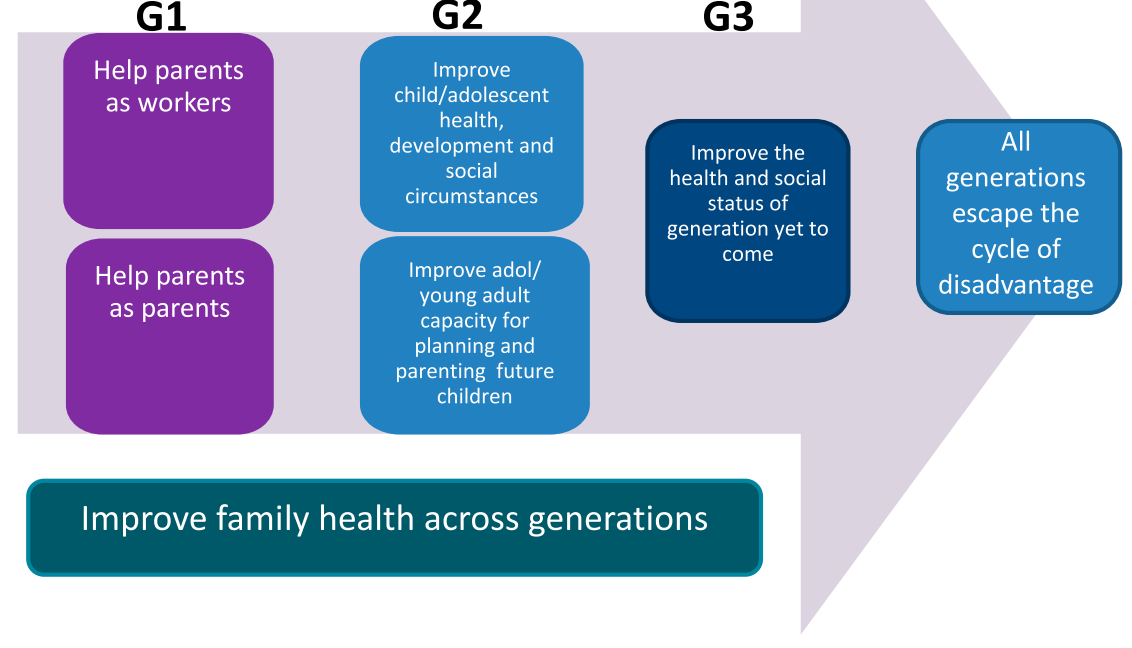

\section{FIGURE 3}

Three-generation approach. Adol, adolescent; G1, generation 1, parents; G2, generation 2, child; G3, generation 3, future offspring. (Adapted with permission from Schmit S, Matthews H, Golden 0. Thriving children, sucessful parents: a two generation approach to policy. CLASP Policy Solutions; July 9, 2014. Available at: http://www.clasp.org/resources-and-publiations/publication-1/Two-GenBrief-FINAL.pdf. Accessed June 14, 2015.)

The 3-Generation Continuum

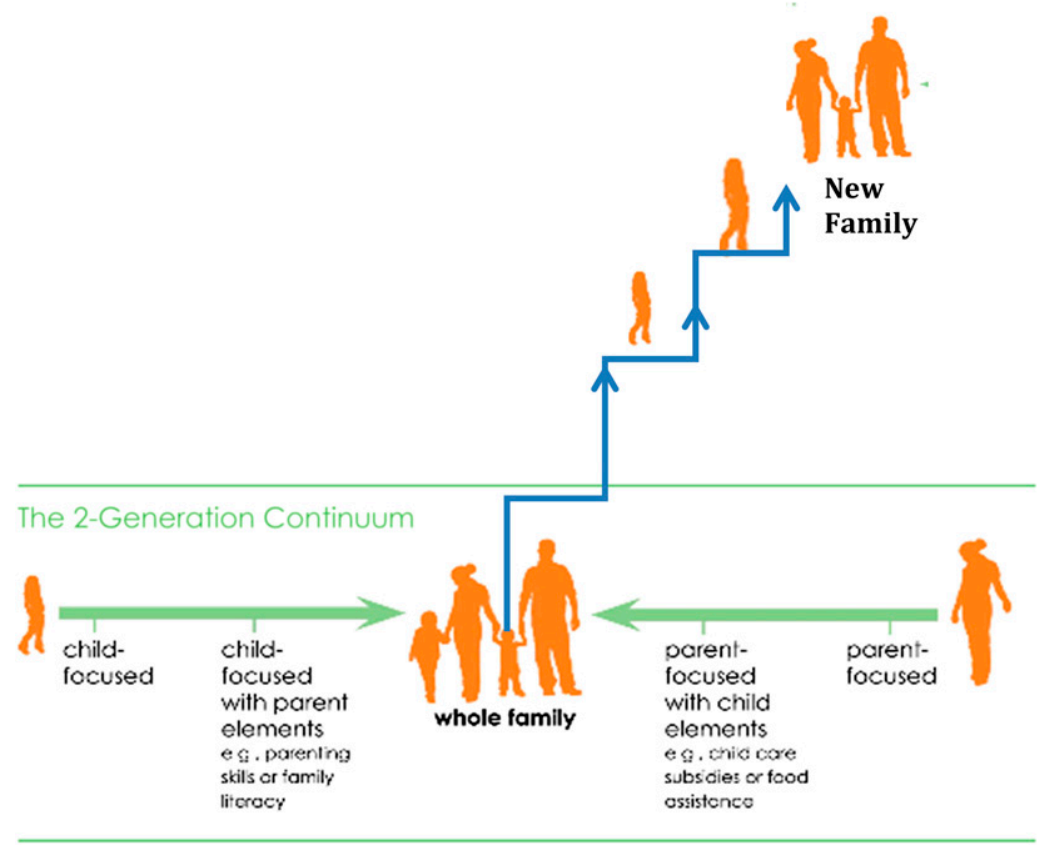

FIGURE 4

The 2- and 3-generation continuums. (Adapted with permission from Ascend: The Aspen Institute. The two generation approach. What is the two generation approach? 2012. Available at: http://ascend. aspeninstitute.org/pages/the-two-generation-approach. Accessed May 31, 2015.) 
investment in the education, health, and availability of employment opportunities for all children to meet their full potential and contribute to society.

\section{Preconception Health}

The 3-generation approach emphasizes the importance of investments during adolescence and early adulthood when choices about family formation are made. There has been increased interest in the preconception health of both women and men to reduce infant mortality and promote child health. ${ }^{86-88}$ Poor women are more likely to face barriers to care and are less likely to have well-woman health visits. ${ }^{89}$ Ensuring that all adolescents and adults of childbearing age have access to quality care and are in optimal health is crucial for a healthy next generation. Pediatric clinicians are important providers of such care. They see preconceptual adolescents and mothers when they bring their children in for care who may be interconceptional for their next child. Thus, pediatric clinicians have an important role in optimizing women's health and the health of the next generation. ${ }^{90}$ For low-income women in particular, pediatric clinicians may be the primary source of contact with the health system. Preconception health care should address genetic family history, medical and psychosocial conditions, medications, substance use, toxins, nutrition, and folate intake regardless of whether planning pregnancy. ${ }^{91,92}$ Payment for this type of health care delivery innovation, as well as policies that support access to care and health promotion for adolescents and young adults, are essential to preconception health.

\section{Reproductive Life Planning}

Reproductive life planning purposefully addresses family planning and preconception health and is an essential component of the 3-generation approach. Half of pregnancies in the United States are unwanted or mistimed. ${ }^{93}$ The degree to which a pregnancy is wanted is associated with indicators of child well-being, ${ }^{91,94,95}$ and child socioemotional development. ${ }^{96}$ Thus, discussions in primary or other care visits regarding future pregnancies and contraceptive needs can help ensure the well-being of future generations. For clinicians who care for adolescents and parents of childbearing age, these discussions include desire for current and future pregnancy, impact of a potential pregnancy on social and economic circumstances, planning for future pregnancy, contraception counseling, vitamins with folate for all women of childbearing age, and counseling on healthy behaviors for potential future pregnancies. ${ }^{92}$ Again, this is a shift in paradigm from a primarily risk assessment/risk reduction approach to one that proactively plans for the future.

\section{Parenting Skills and Capacities}

The 3-generation approach prioritizes building the capacity for responsive parenting through skills development long before reproductive maturity and decisions about family formation are made. The socioemotional skills and capacities that are important for educational engagement and attainment, as well as occupational productivity, are also important for positive social and romantic relationships and responsive parenting. Thus, programs that aim to universally optimize socioemotional skills are an important component of a 3-generation approach. Furthermore, before the choice to be a parent has been made, universal education should be provided on child development, parenting skills, and impact on social and economic circumstances. Such teaching may aid in decision-making regarding timing of parenthood and may prepare young people for effective parenting. Enhanced teaching of parenting skills in primary care can improve parenting practices and reduce child disruptive behaviors. ${ }^{97}$ Other countries have created multiagency, integrated systems of prenatal, parent, and child care supports that may be instructive models. ${ }^{98-100}$ Ultimately, multiple sectors, including health care, education, social services, and community organizations, must take responsibility for ensuring that young people have the skills they need to be responsive, nurturing parents when and if they choose to be.

\section{Implications for Health Care Delivery}

The 3-generation approach necessitates greater longitudinal integration of services across the age spectrum (eg, pediatrics, internal medicine, geriatrics), as well as greater intergenerational integration of services (eg, obstetrics, family medicine) than our current health care delivery system achieves. ${ }^{101}$ Our age-based delivery system creates structural barriers that limit 2- and 3-generation programs. ${ }^{14,45}$ All specialties can provide familyfocused care, thereby contributing to intergenerational health. Integrated health care delivery innovations (eg, pediatric clinicians providing preconception health counseling, parenting education, adolescent transition programs) require study and new payment models. Although electronic medical records have revolutionized the ability to track individuals and populations across the life course, most systems still lack the ability to link and track family members. This would enable more complete family, genetic, and social histories across generations. Finally, in addition to vertical integration of health services across the life course, horizontal integration (merging health services with other service sectors such as child care, schools, and social services) is 
needed to optimize child health and well-being. ${ }^{45,101}$ Again, multisector involvement and collaboration are essential. Technology (longitudinal and family-linked electronic records, enhanced communication mechanisms) could assist in breaking down existing information silos.

\section{Implications for Research}

Electronic medical records offer great opportunity to study health and well-being across the life course and across generations. Linking families electronically is essential. Further study is needed on mechanisms of the life course and intergenerational transmission of SES and health and cross-generational family influences on SES and health. This must include studies on transmission of parenting competencies and effectiveness of interventions to improve parenting skills. Finally, research innovations in program development and implementation and dissemination of 2- and 3-generation approaches are needed documenting effectiveness and cost-effectiveness. This should involve primary care, the health care delivery system, and integration with other sectors such as education, social services, and employment.

\section{Implications for Policy}

Three-generation approaches require investment with an eye toward future generations. Although environmental or health impact assessments consider every policy's impact in those arenas, policies must also be evaluated not on the legacy but the contribution the policy has for the future well-being and health of the next generation. Policies must promote integration of sectors that support children, adolescents, and families, removing silos and recognizing the need for long-term return on investment across sectors. Strategic investment at critical periods (not only critical periods in development, but also at critical inflection points in the transmission of poor health and disadvantage across generations such as pregnancy or prepregnancy) are needed. Concretely, this includes increased commitment to and investment in multigeneration strategies such as universal family planning and parenting education, efforts to improve the quality and safety of schools and child care, as well as policies that support families such as parental leave, child tax credits, minimum wage laws, employment opportunities, and antipoverty initiatives. Although not the focus of this article, it is clear that economic and governmental policies are a critical part of solutions to eliminate intergenerational poverty and health disparities.

\section{CONCLUSIONS}

Maximizing a child's health, well-being, and development optimizes potential for that child to become a productive adult. Such investment in future generations is also an investment in society at large and a way to reduce intergenerational health disparities. Child health professionals can help optimize children's and adolescents' biological, behavioral, and psychosocial capacities and resources both to maximize that individual's own health and social circumstances as well as to support those of the next generation. This means supporting not only 2-generation strategies involving children and parents but also purposeful 3-generation strategies that bolster children's capacity to become healthy, engaged, happy, and successful citizens and nurturing, capable future parents.

ABBREVIATIONS
DoHAD: developmental origins of
$\quad$ adult disease
LBW: low birth weight
LCHD: Life Course Health
Development
SES: socioeconomic status
SGA: small for gestational age

FINANCIAL DISCLOSURE: The authors have indicated they have no financial relationships relevant to this article to disclose.

FUNDING: This publication was supported by the DC-Baltimore Research Center on Child Health Disparities (grant P20 MD000198) from the National Institute on Minority Health and Health Disparities (TLC), Centro SOL, Johns Hopkins Center for Salud/(Health) and Opportunity for Latinos (TLC), and the Rales Center on the Integration of Health and Education (SBJ, TLC). The content is solely the responsibility of the authors and does not necessarily represent the official views of the funding agencies. Funded by the National Institutes of Health (NIH).

POTENTIAL CONFLICT OF INTEREST: The authors have indicated they have no potential conflicts of interest to disclose.

\section{REFERENCES}

1. US Department of Health and Human Services. Healthy People 2020. 2011 Available at: http://www.healthypeople. gov/2020. Accessed June 20, 2015

2. American Academy of Pediatrics. AAP Agenda for Children-Strategic Plan. 2014. Available at: http://www.aap. org/en-us/about-the-aap/aap-facts/
AAP-Agenda-for-Children-Strategic-Plan/ Pages/AAP-Agenda-for-Children-StrategicPlan.aspx. Accessed June 20, 2015

3. National Research Council. Unequal Treatment: Confronting Racial and Ethnic Disparities in Health Care. Washington, DC: The National Academies Press; 2003
4. DeNavas-Walt C, Proctor B. Current Population Reports P60-249: Income and Poverty in the United States: 2013. Washington, DC: US Census Bureau; 2014

5. Duncan GJ, Ziol-Guest KM, Kalil A. Early-childhood poverty and adult attainment, behavior, and health. Child Dev. 2010;81(1):306-325 
6. Adler NE, Stewart J. Health disparities across the lifespan: meaning, methods, and mechanisms. Ann N Y Acad Sci. 2010;1186:5-23

7. Shonkoff JP, Garner AS; Committee on Psychosocial Aspects of Child and Family Health; Committee on Early Childhood, Adoption, and Dependent Care; Section on Developmental and Behavioral Pediatrics. The lifelong effects of early childhood adversity and toxic stress. Pediatrics. 2012;129(1). Available at: www.pediatrics.org/cgi/ content/full/129/1/e232

8. Evans GW, Kim P. Multiple risk exposure as a potential explanatory mechanism for the socioeconomic statushealth gradient. Ann N Y Acad Sci. 2010;1186:174-189

9. Gluckman PD, Hanson MA. The conceptial basis for the developmental origins of health and disease. In: Gluckman PD, Hanson MA, eds. Developmental Origins of Health and Disease. Cambridge, UK: Cambridge University Press; 2006:33-50

10. Gluckman PD, Hanson MA, Beedle AS. Early life events and their consequences for later disease: a life history and evolutionary perspective. Am J Hum Biol. 2007;19(1):1-19

11. Hanson MA, Gluckman PD. Developmental origins of health and disease-global public health implications. Best Pract Res Clin Obstet Gynaecol. 2015;29(1):24-31

12. Aizer A, Currie J. The intergenerational transmission of inequality: maternal disadvantage and health at birth. Science. 2014;344(6186):856-861

13. National Human Services Assembly. Breaking the cycle of poverty in young families: two-generation strategies for working with disconnected young parents \& their children. 2013. Available at: http://www.nassembly. org/knowledge/documents/NHSAFull_ Report2Gen0SOWFamilies.pdf. Accessed May 13, 2015

14. McLanahan SCJ, Haskins R, Rouse CE, Sawhill I. Helping parents, helping children: two-generation mechanisms. Future Child. 2014;24(1):1-174

15. Hales CN, Barker DJ. Type 2 (non-insulin-dependent) diabetes mellitus: the thrifty phenotype hypothesis. Diabetologia.

1992;35(7):595-601

16. Halfon N, Larson K, Lu M, Tullis E, Russ S. Lifecourse health development: past, present and future. Matern Child Health J. 2014;18(2):344-365

17. Fine A, Kotelchuck M. Rethinking MCH: The Life Course Model as an Organizing Framework. Washington, DC: US Dept Health Human Services; November 2010

18. Sterling P, Eyer J. Allostasis: a new paradigm to explain arousal pathology. In: Fisher S, ed. Handbook of Life Stress, Cognition and Health. New York, NY: John Wiley \& Sons; 1988

19. McEwen BS. Protective and damaging effects of stress mediators. $N$ Engl J Med. 1998;338(3):171-179

20. McEwen BS. From molecules to mind. Stress, individual differences, and the social environment. Ann N Y Acad Sci. 2001;935(1):42-49

21. Thompson 0. Genetic mechanisms in the intergenerational transmission of health. J Health Econ. 2014;35:132-146

22. Godfrey KM, Barker DJ. Maternal nutrition in relation to fetal and placental growth. Eur J Obstet Gynecol Reprod Biol. 1995;61(1):15-22

23. Hertzman C, Boyce T. How experience gets under the skin to create gradients in developmental health. Annu Rev Public Health. 2010;31:329-347

24. Phillips DI, Barker DJ, Fall CH, et al. Elevated plasma cortisol concentrations: a link between low birth weight and the insulin resistance syndrome? J Clin Endocrinol Metab. 1998;83(3):757-760

25. Schulz LC. The Dutch Hunger Winter and the developmental origins of health and disease. Proc Natl Acad Sci USA. 2010;107 (39):16757-16758

26. Barker DJ. The malnourished baby and infant. Br Med Bull. 2001;60:69-88

27. Fall CH, Sachdev HS, Osmond C, et al; New Delhi Birth Cohort. Adult metabolic syndrome and impaired glucose tolerance are associated with different patterns of BMI gain during infancy: data from the New Delhi Birth Cohort. Diabetes Care. 2008;31(12):2349-2356
28. Barker DJ, Fall CH. Fetal and infant origins of cardiovascular disease. Arch Dis Child. 1993;68(6):797-799

29. Vaag AA, Grunnet LG, Arora GP Brøns C. The thrifty phenotype hypothesis revisited. Diabetologia 2012;55(8):2085-2088

30. Ibáñez L, Ong K, Dunger DB, de Zegher F. Early development of adiposity and insulin resistance after catch-up weight gain in small-for-gestationalage children. J Clin Endocrinol Metab. 2006;91(6):2153-2158

31. Barker DJP, Osmond C, Forsén TJ, Kajantie E, Eriksson JG. Trajectories of growth among children who have coronary events as adults. $N$ Engl J Med. 2005;353(17):1802-1809

32. Eriksson J, Forsén T, Osmond C, Barker D. Obesity from cradle to grave. Int J Obes Relat Metab Disord. 2003;27 (6):722-727

33. Salonen MK, Kajantie E, Osmond C, et al. Role of childhood growth on the risk of metabolic syndrome in obese men and women. Diabetes Metab. 2009;35(2):94-100

34. Tu Y-K, West R, Ellison GTH, Gilthorpe MS. Why evidence for the fetal origins of adult disease might be a statistical artifact: the "reversal paradox" for the relation between birth weight and blood pressure in later life. Am J Epidemiol. 2005;161(1):27-32

35. Meaney MJ. Maternal care, gene expression, and the transmission of individual differences in stress reactivity across generations. Annu Rev Neurosci. 2001;24:1161-1192

36. Weaver IC, Cervoni N, Champagne FA, et al. Epigenetic programming by maternal behavior. Nat Neurosci. 2004; 7 (8):847-854

37. Meaney MJ, Szyf M. Environmental programming of stress responses through DNA methylation: life at the interface between a dynamic environment and a fixed genome. Dialogues Clin Neurosci. 2005; (2):103-123

38. Halfon N, Hochstein M. Life Course Health Development: an integrated framework for developing health, policy, and research. Milbank $Q$. 2002;80(3):433-479 
39. Polderman TJC, Benyamin B, de Leeuw CA, et al. Meta-analysis of the heritability of human traits based on fifty years of twin studies. Nat Genet. 2015;47(7):702-709

40. McEwen BS, Gianaros PJ. Stress- and allostasis-induced brain plasticity. Annu Rev Med. 2011;62:431-445

41. Miller GE, Chen E, Fok AK, et al. Low early-life social class leaves a biological residue manifested by decreased glucocorticoid and increased proinflammatory signaling. Proc Natl Acad Sci USA. 2009;106(34):14716-14721

42. Fernald LC, Gunnar MR. Povertyalleviation program participation and salivary cortisol in very lowincome children. Soc Sci Med. 2009;68(12):2180-2189

43. Ascend: The Aspen Institute. The two generation approach. What is the two generation approach? 2012. Available at: http://ascend.aspeninstitute.org/ pages/the-two-generation-approach . Accessed May 31, 2015

44. Schmit S, Matthews H, Golden 0 . Thriving children, successful parents: a two-generation approach to policy. CLASP Policy Solutions; 2014. Available at: http://www.clasp.org/ resourcesand-publications/publication-1/Two-GenBrief-FINAL.pdf. Accessed June 14, 2015

45. Glied S, Oellerich D. Two-generation programs and health. Future Child. 2014;24(1):79-97

46. The John D and Catherine T. MacArthur Research Network on Socioeconomic Status and Health. Reaching for a healthier life: facts on socioeconomic status and health in the U.S. Available at: http://www.macses.ucsf.edu/ downloads/Reachingfor_a_Healthier_ Life.pdf. Accessed June 27, 2015

47. Alexander K, Entwistle D, Olson L. The Long Shadow: Family Background, Disadvantaged Urban Youth, and the Transition to Adulthood (American Sociological Association's Rose Series in Sociology). New York, NY: Russell Sage Foundation; 2014

48. Mazumder B. Black-white differences in intergenerational economic mobility in the United States. Federal Reserve Bank of Chicago Economic Perspectives. 2014;(Q1):1-18
49. Johnson MK, Crosnoe R, Elder GH Jr Insights on adolescence from a life course perspective. J Res Adolesc. 2011;21(1):273-280

50. Currie J, Moretti E. Biology as destiny? Short-and long run determinants of intergenerational transmission of birth weight. J Labor Econ. 2007;25(2):231-264

51. Office of Head Start AfCaF. History of Head Start. 2015. Available at: http:// www.acf. hhs.gov/programs/ohs/ about/history-of-head-start. Accessed November 6, 2015

52. Mortensen LH, Diderichsen F, Arntzen A, et al. Social inequality in fetal growth: a comparative study of Denmark, Finland, Norway and Sweden in the period 1981-2000. J Epidemiol Community Health. 2008;62(4): 325-331

53. Abu-Saad K, Fraser D. Maternal nutrition and birth outcomes. Epidemiol Rev. 2010;32(1):5-25

54. Phares T, Morrow B, Lansky A, Barfield W. Surveillance for disparities in maternal health-related behaviors selected states, Pregnancy Risk Assessment Monitoring System (PRAMS), 2000-2001. MMWR Surveillance Summaries; 2004

55. Nomura Y, Wickramaratne PJ, Pilowsky DJ, et al. Low birth weight and risk of affective disorders and selected medical illness in offspring at high and low risk for depression. Compr Psychiatry. 2007;48(5):470-478

56. Bell JF, Zimmerman FJ, Almgren GR, Mayer JD, Huebner CE. Birth outcomes among urban African-American women: a multilevel analysis of the role of racial residential segregation. Soc Sci Med. 2006;63(12):3030-3045

57. Hansen CA, Barnett AG, Pritchard G. The effect of ambient air pollution during early pregnancy on fetal ultrasonic measurements during midpregnancy. Environ Health Perspect. 2008;116(3):362-369

58. Schofield TJ, Martin MJ, Conger KJ, Neppl TM, Donnellan MB, Conger RD. Intergenerational transmission of adaptive functioning: a test of the interactionist model of SES and human development. Child Dev. 2011;82(1):33-47
59. Bowlby J. A Secure Base: Parent-Child Attachment and Healthy Human Development. New York, NY: Basic Books; 1988

60. Bandura A. Social Learning Theory. Englewood Cliffs, NJ: Prentice-Hall; 1977

61. Beaver KM, Belsky J. Geneenvironment interaction and the intergenerational transmission of parenting: testing the differentialsusceptibility hypothesis. Psychiatr $Q$. 2012;83(1):29-40

62. Meaney M, Tannenbaum B, Francis $D$, et al. Early environmental programming hypothalamic-pituitaryadrenal responses to stress. Semin Neurosci. 1994;6:247-259

63. Chen Z-y, Kaplan HB. Intergenerational transmission of constructive parenting. J Marriage Fam. 2001;63(1):17-31

64. Baumrind D. The influence of parenting style on adolescent competence and substance use. J Early Adolesc. 1991;11(1):56-95

65. Bailey JA, Hill KG, Oesterle S, Hawkins JD. Parenting practices and problem behavior across three generations: monitoring, harsh discipline, and drug use in the intergenerational transmission of externalizing behavior. Dev Psychol. 2009;45(5):1214-1226

66. Scaramella LV, Neppl TK, Ontai $\mathrm{LL}$, Conger RD. Consequences of socioeconomic disadvantage across three generations: parenting behavior and child externalizing problems. $J$ Fam Psychol. 2008;22(5):725-733

67. Brook JS, Zhang C, Balka EB, Brook DW Pathways to children's externalizing behavior: a three-generation study. J Genet Psychol. 2012;173(2):175-197

68. Capaldi DM, Pears KC, Patterson GR, Owen LD. Continuity of parenting practices across generations in an at-risk sample: a prospective comparison of direct and mediated associations. J Abnorm Child Psychol. 2003;31(2):127-142

69. Conger RD, Neppl T, Kim KJ, Scaramella L. Angry and aggressive behavior across three generations: a prospective, longitudinal study of parents and children. J Abnorm Child Psychol. 2003;31(2):143-160 
70. Hops H, Davis B, Leve C, Sheeber L. Cross-generational transmission of aggressive parent behavior: a prospective, mediational examination. J Abnorm Child Psychol. 2003;31(2):161-169

71. Neppl TK, Conger RD, Scaramella LV, Ontai LL. Intergenerational continuity in parenting behavior: mediating pathways and child effects. Dev Psychol. 2009;45(5):1241-1256

72. Smith CA, Farrington DP. Continuities in antisocial behavior and parenting across three generations. J Child Psychol Psychiatry. 2004;45(2): 230-247

73. Thornberry TP, Freeman-Gallant A, Lizotte AJ, Krohn MD, Smith CA. Linked lives: the intergenerational transmission of antisocial behavior. J Abnorm Child Psychol. 2003;31(2):171-184

74. Fomby P, Krueger PM, Wagner NM. Age at childbearing over two generations and grandchildren's cognitive achievement. Res Soc Stratif Mobil. 2014;35(0):71-88

75. Health Resources and Services Administration. Maternal, infant, and early childhood home visiting. 2015. Available at: http://mchb.hrsa.gov/ programs/homevisiting/. Accessed September 26, 2015

76. Sareen J, Afifi T0, McMillan KA, Asmundson GJ. Relationship between household income and mental disorders: findings from a populationbased longitudinal study. Arch Gen Psychiatry. 2011;68(4):419-427

77. Hudson CG. Socioeconomic status and mental illness: tests of the social causation and selection hypotheses. Am J Orthopsychiatry. 2005;75(1):3-18

78. Gilman SE, Kawachi I, Fitzmaurice GM, Buka L. Socio-economic status, family disruption and residential stability in childhood: relation to onset, recurrence and remission of major depression. Psychol Med. 2003;33(8):1341-1355

79. Warner V, Weissman MM, Mufson L, Wickramaratne PJ. Grandparents, parents, and grandchildren at high risk for depression: a three-generation study. J Am Acad Child Adolesc Psychiatry. 1999;38(3):289-296
80. Weissman MM, Wickramaratne $P$, Nomura $Y$, et al. Families at high and low risk for depression: a 3-generation study. Arch Gen Psychiatry. 2005;62 (1):29-36

81. Ehrensaft MK, Cohen P. Contribution of family violence to the intergenerational transmission of externalizing behavior. Prev Sci. 2012;13(4):370-383

82. Mosle A, Patel N, Stedron J. Top 10 for 2Gen: Policy Ideas and Principles to Advance Two-Generation Efforts. Washington, DC: Ascend: The Aspen Institute; 2014

83. Heckman JJ, Masterov DV. The productivity argument for investing in young children. Appl Econ Perspect Policy. 2007;29(3):446-493

84. Heckman JJ. Skill formation and the economics of investing in disadvantaged children. Science. 2006;312(5782):1900-1902

85. Wise PH. Confronting social disparities in child health: a critical appraisal of life-course science and research. Pediatrics. 2009;124(suppl 3):S203-S211

86. Johnson K, Posner SF, Biermann $J$, et al; CDC/ATSDR Preconception Care Work Group; Select Panel on Preconception Care. Recommendations to improve preconception health and health care-United States. A report of the CDC/ATSDR Preconception Care Work Group and the Select Panel on Preconception Care. MMWR Recomm Rep. 2006;55(RR-6 RR06):1-23

87. Markus A, Atrash H, Johnson K. Women's health issues: policy and financing issues for preconception and interconception health. Womens Health Issues. 2008;18(6 suppl):S1-S125

88. Ramey SL, Schafer P, DeClerque JL, et al; Community Child Health Network. The preconception stress and resiliency pathways model: a multilevel framework on maternal, paternal, and child health disparities derived by community-based participatory research. Maternal Child Health J. 2015;19(4):707-719

89. Board on Population Health and Public Health Practice I0M. Clinical Preventive Services for Women: Closing the Gaps. Washington, DC: The National Academies Press; 2011
90. Cheng TL, Kotelchuck M, Guyer B. Preconception women's health and pediatrics: an opportunity to address infant mortality and family health. Acad Pediatr. 2012;12(5):357-359

91. Shah PS, Balkhair T, Ohlsson A, Beyene J, Scott F, Frick C. Intention to become pregnant and low birth weight and preterm birth: a systematic review. Matern Child Health J. 2011;15(2):205-216

92. Jack BWAH, Atrash H, Coonrod DV, Moos MK, O’Donnell J, Johnson K. The clinical content of preconception care: an overview and preparation of this supplement. Am J Obstet Gynecol. 2008;199 (6 suppl 2): S266-S279

93. Finer LBZM, Zolna MR. Unintended pregnancy in the United States: incidence and disparities, 2006. Contraception. 2011;84(5):478-485

94. Korenman S, Kaestner R, Joyce T. Consequences for infants of parental disagreement in pregnancy intention. Perspect Sex Reprod Health. 2002;34(4):198-205

95. Patel SA, Surkan PJ. Unwanted childbearing and household food insecurity in the United States. Matern Child Nutr. 2016;12(2): 362-372

96. Saleem HT, Surkan PJ. Parental pregnancy wantedness and child social-emotional development. Matern Child Health J. 2014;18(4):930-938

97. Perrin ECSC, Sheldrick RC, McMenamy JM, Henson BS, Carter AS. Improving parenting skills for families of young children in pediatric settings: a randomized clinical trial. JAMA Pediatr. 2014;168(1):16-24

98. United Kingdom Department for Education. What local authorities need to know about running Sure Start Children's Centres. 2014. Available at: http://www.education. gov.uk/childrenandyoungpeople/ earlylearningandchildcare/delivery/ surestart/a0076712/sure-startchildren's-centres. Accessed June 27, 2014

99. National Evaluation of Sure Start Research Team. The impact of Sure Start local programmes on three year 
olds and their families. 2008. Available at: http://www.ness.bbk.ac.uk/impact/ documents/42.pdf. Accessed June 27, 2015

100. Anning A, National Evaluation of Sure Start Team (NESST).
Understanding variations in effectiveness amongst Sure Start Local Programmes: Iessons for Sure Start Children's Centres. 2007. Available at: http://https://www. education.gov.uk/publications/
e0rderingDownload/NESS2007SF024. pdf Accessed June 27, 2015

101. Cheng TL, Solomon BS. Translating life course theory to clinical practice to address health disparities. Matern Child Health J. 2014;18(2):389-395 